\title{
Effect of Sulfuric Acid and Fermentation Time on Bioethanol Production from Empty Fruit Bunch (EFB)
}

\author{
Martha Aznury ${ }^{1, *}$ Ahmad Zikri ${ }^{1}$ Aisyah Suci Ningsih ${ }^{1}$ Siti Chodijah ${ }^{1}$ Felisia Hanura ${ }^{1}$ \\ Muhammad Albarr Aksa ${ }^{1}$ Nova Rachmadona ${ }^{2}$ \\ ${ }^{1}$ Department of Chemical Engineering, Politeknik Negeri Sriwijaya, Palembang, Indonesia \\ ${ }^{2}$ Department of Chemical Science and Engineering, Graduate School of Engineering, Kobe University, Japan \\ *Corresponding author. Email: martha_aznury@polsri.ac.id
}

\begin{abstract}
The limited stock of non-renewable fuels has caused the necessity of finding alternative renewable and substitute fuels such as bioethanol. However, the high cost of the raw materials and the risk of transferring agricultural lands are the main obstacle to production and loss in food supplies. Therefore, the utilization of palm oil waste, empty fruit bunches (EFB), can solve this problem. This study aims to determine the optimum fermentation condition of bioethanol production by using $\mathrm{NaOH}$ and $\mathrm{H}_{2} \mathrm{SO}_{4}$ for degrading the lignin and converting cellulose to glucose. Three concentrations of $\mathrm{H}_{2} \mathrm{SO}_{4}$ were used in the fermentation process. In addition, refractive index, $\mathrm{pH}$, and ethanol content were analyzed to measure the bioethanol.
\end{abstract}

Keywords: Oil Palm Empty Fruit Bunches, $\mathrm{H}_{2} \mathrm{SO}_{4}$, Bioethanol, Saccharomycs cerevisiae

\section{INTRODUCTION}

Indonesia is a country with a wealth of natural resources, where there are renewable and non-renewable natural resources such as petroleum fuel. The depletion of petroleum resources and other fuel sources in Indonesia encourages alternative energy to support energy needs. So far, the efforts carried out include using materials containing sugar and starch that can be processed into fuel.

One alternative energy that is still being developed at this time is bioethanol. Bioethanol is a liquid resulting from sugar fermentation from carbohydrates with various advantages, including renewable, environmentally friendly, and economically advantageous. Therefore, alternative and potential sources of raw materials are sought, namely biomass. This biomass has no potential in feed and food, and it is available in abundance and is cheaper. The alternative obtained is the use of cellulose materials. Cellulose materials can be used as bioethanol because when hydrolyzed, cellulose materials will produce sugar and continue to do so by fermentation will produce bioethanol [1]. In addition, cellulose materials are found in abundance in Indonesia because cellulose materials are agricultural wastes such as rice straw, bagasse, empty fruit bunches (EFB), and grasses. This cellulose material is very cheap and can even be obtained for free. The use of cellulose material as raw material for bioethanol can increase the benefits or added value of agricultural waste because it has been used so far. Unfortunately, agricultural waste is not utilized optimally. This study using materials from agricultural waste, namely.

Oil palm (Elaesis guineenis) is a plantation crop that plays an important role in the food industry [2]. Palm oil production in Indonesia in 2019 increased compared to the previous year to reach 30.06 million tons [3]. It is known that 1 ton of palm oil will be able to produce waste in the form of empty palm oil bunches as much as $23 \%$ or $230 \mathrm{~kg}$, shell waste as much as $6.5 \%$ or $65 \mathrm{~kg}$, wet decanter solid (palm mud) $4 \%$ or $40 \mathrm{~kg}$, fiber (fiber) $13 \%$ or $130 \mathrm{~kg}$ and $50 \%$ liquid waste [4].

\subsection{Empty Fruit Bunches (EFB)}

The palm oil processing process produces byproducts in the form of palm oil waste. Based on the place of formation, palm oil waste can be classified into two types, namely oil palm plantation waste and oil palm industrial waste. Palm oil industry waste is waste generated in the palm oil processing process. This type 
of waste is classified into three types: solid, liquid, and gas waste [5].

Fresh fruit bunches contain 25-34\% empty fruit bunches, and oil palm empty bunches have three main components: cellulose, hemicellulose, and lignin [6]. However, so far, EFB has only been used as organic fertilizer, raw material for making paper, briquettes, and generally, it has only come to the use of fiber as a filling material for a medium such as filling car seat cavities and mattresses [7].

Whereas EFB can be developed into more valuable goods, one of which is the raw material for bioethanol because EFB contains a lot of cellulose which can be hydrolyzed into glucose and then fermented into bioethanol. The high cellulose content of $45 \%$ makes oil palm a priority to be used as a raw material for making bioethanol.

\subsection{Pretreatment}

Pretreatment is an important step for the production of ethanol. This stage involves several processes that change the biomass's size, structure, and chemical content to optimize hydrolysis conditions. The principle of pretreatment is to increase the ability of the material by unbinding the complex lignocellulosic structure. The pretreatment method can be done in 3 ways, namely physically, chemically, and biologically. In addition, many studies have used a combination of physical and chemical treatment [8].

The purpose of pretreatment is to open the structure of lignin cellulose so that the cellulose becomes more accessible to enzymes that break down polysaccharide polymers into sugar monomers. Thus, pretreatment alters the structure of cellulose biomass to make cellulose more accessible to enzymes that convert carbohydrate polymers. Furthermore, when lignocellulose is separated into its components, it can be hydrolyzed into glucose [9]. Glucose can then be further converted to valuable bio-based chemicals.

\subsection{Hydrolysis}

Hydrolysis is a chemical reaction that breaks down several molecules with water molecules to convert polysaccharides into monomers such as glucose [10]. For example, on complete hydrolysis, cellulose will produce glucose while hemicellulose will produce pentose (C5) and hexose (C6) sugar monomers.

\subsection{Fermentation}

Fermentation is a process of chemical change in an organic substrate through the activity of enzymes produced by microorganisms [11]. At first, the term fermentation was used to denote the process of converting glucose into ethanol. Then, the term fermentation developed again into a whole overhaul of organic compounds carried out by microorganisms involving the enzymes they produce. In other words, Fermentation is a change in the chemical structure of organic materials by utilizing biological agents, especially enzymes as biocatalysts.

\section{MATERIAL AND METHOD}

\subsection{Materials}

EFB from Hidolli Company, Saccharomyces cerevisiae, $\mathrm{dH}_{2} \mathrm{O}, \mathrm{NaOH}(5 \%), \mathrm{H}_{2} \mathrm{SO}_{4}$ with $2 \%, 3 \%$, and $4 \%$. Glassware equipment (Pyrex, USA)

\subsection{Methods}

\subsubsection{Pretreatment of $E F B$}

- Drying OPEFB in the hot sun and the oven for 60 minutes

- Smooth the OPEFB to the desired size

- Weighing 25 grams of EFB, put into $500 \mathrm{ml}$ Erlenmeyer

- Added $150 \mathrm{ml} 5 \% \mathrm{NaOH}$, then heated at a temperature of $100^{\circ} \mathrm{C}$ for 60 minutes. Then cooled at room temperature

- Separating the aqueous phase so that the cellulose, hemicellulose, and lignin phase remains

\subsubsection{Hydrolysis Process}

- Make a solution to hydrolyze EFB as much as 120 $\mathrm{ml}$ per sample. With variations in the concentration of $\mathrm{H}_{2} \mathrm{SO}_{4}(2 \%, 3 \%$, and $4 \%)$

- The pretreatment results are put into an Erlenmeyer and then added with a previously prepared $\mathrm{H}_{2} \mathrm{SO}_{4}$ solution.

- Then, the mixture is heated at a temperature of $80^{\circ} \mathrm{C}$ for 60 minutes.

- Cellulose substrate that has been hydrolyzed is cooled for 30 minutes.

- After cooling, the solution is filtered to separate the glucose solution from the dissolved solids to obtain glucose.

\subsubsection{Fermentation Process}

-Adjust the temperature and $\mathrm{pH}$ of the hydrolyzed solution at $30^{\circ} \mathrm{C}$ and $\mathrm{pH}=4-5$

- Hydrolysis solution obtained later fermented by adding 2.5 grams Saccharomyes cerevisiae

- Put into the reactor and incubate for 48,72 , and 120 hours 


\subsubsection{Distillation Process}

Fermented products are distilled at temperature $80^{\circ} \mathrm{C}$ for 2.5 hours

\subsection{Analysis Procedure}

Determination of Refractive Index was using SNI 01-1940-1990 method (SNI, 1990). For measuring pH value with SNI 01-2891-1992 (SNI,1992). Determination of Ethanol levels using ATC Alcohol Refractometer.

\section{RESULT AND DISCUSSION}

In this study, the addition of $\mathrm{H}_{2} \mathrm{SO}_{4}$ carried out in the hydrolysis step, where the concentrations of the $\mathrm{H}_{2} \mathrm{SO}_{4}$ were $2 \%, 3 \%$, and $4 \%$, respectively. Thus, $\mathrm{H}_{2} \mathrm{SO}_{4}$ catalyzes the hydrolysis process, which breaks the polymer chains of EFB to produce glucose monomers used as raw materials for bioethanol production.

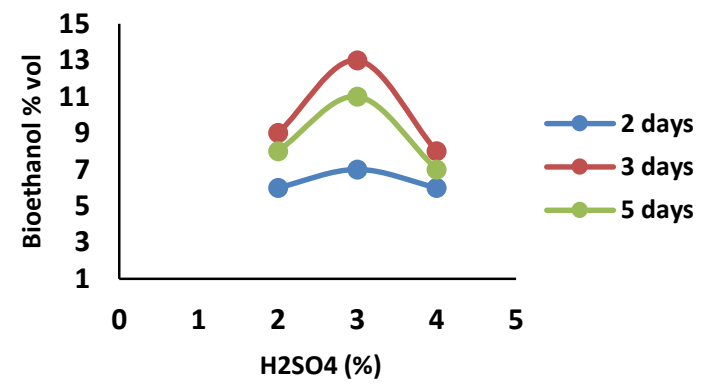

Figure 1. Effect of $\mathrm{H}_{2} \mathrm{SO}_{4}$ on Bioethanol production

With the help of heating at a temperature of $80^{\circ} \mathrm{C}$, $\mathrm{H}_{2} \mathrm{SO}_{4}$ will increase the amount of cellulose in hydrolyzed algae, $\mathrm{H}_{2} \mathrm{SO}_{4}$ dissociate to form $\mathrm{H}+$ ions from $\mathrm{H}_{2} \mathrm{SO}_{4}$. In addition, it will break the cellulose polymer chain to form free radicals and react with $\mathrm{OH}$ ions from water to form glucose monomers.

Determination of the ethanol content was carried out using an alcohol refractometer. It can be seen from Figure 1 that the addition of $\mathrm{H}_{2} \mathrm{SO}_{4}$ concentration 4 affects the ethanol content produced. An increase in $\mathrm{H}_{2} \mathrm{SO}_{4}$ concentration at $3 \%$ showed a good effect on the ethanol content. This occurs due to the increase in the concentration of $\mathrm{H}_{2} \mathrm{SO}_{4}$, increasing the glucose content in the hydrolyzed solution. With the increase in glucose content, the ethanol content produced can also increase. The level of $\mathrm{H}+$ ions has a maximum limit because if the $\mathrm{H}+$ ion has exceeded the maximum limit. Therefore, there will be a decrease in the hydrolysis of cellulose caused by high acid levels in the mixture so that a good $\mathrm{pH}$ is not achieved in the hydrolysis process, which is around 2-3. It can be seen in the graph that there is a decrease in ethanol content at a concentration of $4 \%$. In comparison, the optimum point is at a concentration of $3 \%$. This proves that the optimal concentration of the hydrolysis process is at the concentration of $\mathrm{H}_{2} \mathrm{SO}_{4} 3 \%$.

It can be seen that the fermentation time affects the concentration. For example, the effect of the fermentation time obtained for the 2-day fermentation time, the highest purity level obtained was $7 \%$. For the 3 -day fermentation, the highest purity level was $13 \%$, and at the 5-day fermentation time, the highest purity obtained was $11 \%$. For another treatment bisulfite pretreatment with $8 \% \quad \mathrm{NaHSO}_{3}$ and $1 \% \mathrm{H}_{2} \mathrm{SO}_{4}$, the glucose yield of the enzyme hydrolysis was $0.318 \mathrm{~g} / \mathrm{g}$ EFB after $72 \mathrm{~h} \mathrm{[12]}$

Rate The highest purity of bioethanol obtained in this study was seen from variations in the concentration of $\mathrm{H}_{2} \mathrm{SO}_{4}$, and fermentation time was $13 \%$ with a 3 days. While the lowest level of bioethanol purity obtained was $6 \%$, with a concentration of $2 \% \quad \mathrm{H}_{2} \mathrm{SO}_{4}$ and a fermentation time of 2 days, since during the 2-day fermentation period, the new microorganisms entered the stage of breeding, so that only a small amount of glucose was broken down into bioethanol. For the 3-day fermentation time, it is the stage for the proliferation of microorganisms so that the amount of glucose that becomes bioethanol is quite a lot. While the fermentation time is five days, the microorganisms have entered the stage to the death phase so that only a small amount of glucose is broken down into bioethanol. Produce an optimum yield of total sugars of $98.89 \mathrm{mg} / \mathrm{L}$ from biomass EFB is ethanol $55 \%$ vol $\left(\mathrm{C}_{2} \mathrm{H}_{5} \mathrm{OH}\right)$, at $120^{\circ} \mathrm{C}$ for $60 \mathrm{~min}$ [13].

The effect of $\mathrm{H}_{2} \mathrm{SO}_{4}$ on the resulting bioethanol refractive index can be seen as the difference in Figure 2 below.

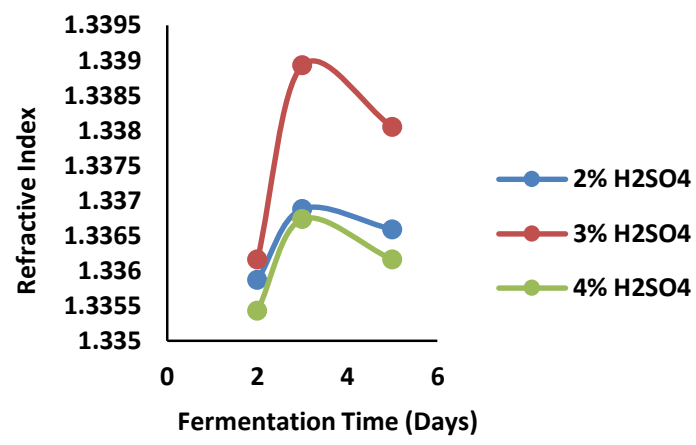

Figure 2. $\mathrm{H}_{2} \mathrm{SO}_{4}$ Concentration on the Refractive Index of Bioethanol

The relationship between the concentration of $\mathrm{H}_{2} \mathrm{SO}_{4}$ in the hydrolysis process on the value of the refractive index was presented in Figure 2. The effect of the concentration of $\mathrm{H}_{2} \mathrm{SO}_{4} \mathrm{O}$ the sample with a concentration of $2 \% \quad \mathrm{H}_{2} \mathrm{SO}_{4}$ obtained the highest refractive index value is 1.33688 , for concentration $3 \%$ 
$\mathrm{H}_{2} \mathrm{SO}_{4}$ the highest refractive index value is 1.33893 , and at concentration $4 \% \mathrm{H}_{2} \mathrm{SO}_{4}$ the highest refractive index value is 1.337471 . The refractive index value increased with the addition of $3 \%$ concentration but decreased with the addition of a higher concentration of $4 \%$.

The effect of fermentation time on the $\mathrm{pH}$ value of the resulting bioethanol can be seen in Figure 3

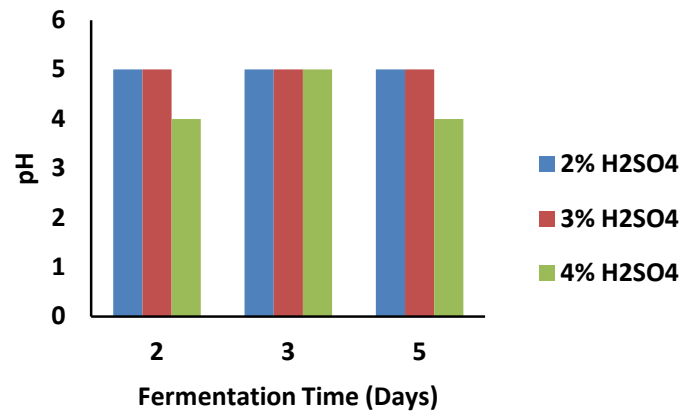

Figure 3 Effect of Fermentation Time on the $\mathrm{pH}$ of Bioethanol Produced

Analysis of the $\mathrm{pH}$ value or degree of acidity in bioethanol is carried out after Fermentation, and the distillation process aims to determine the $\mathrm{pH}$ value of the resulting product, measuring the $\mathrm{pH}$ value directly using a universal $\mathrm{pH}$ meter. The $\mathrm{pH}$ value can be seen in Figure 4.6 above. The $\mathrm{pH}$ value of bioethanol from the bar graph above shows that the $\mathrm{pH}$ value formed is almost the same, namely between 4-5, the lowest $\mathrm{pH}$ value is obtained at two days of Fermentation with a concentration of $\mathrm{H}_{2} \mathrm{SO}_{4} 4 \%$. At five days of Fermentation with a concentration of $\mathrm{H}_{2} \mathrm{SO}_{4}$, which is $4 \%$, the $\mathrm{pH}$ value, which tends to be acidic, is also influenced by the addition of $\mathrm{H}_{2} \mathrm{SO}_{4}$ in the hydrolysis process where the higher the concentration of $\mathrm{H}_{2} \mathrm{SO}_{4}$ used, the $\mathrm{pH}$ value of bioethanol tends to decrease. In the fermentation process, the longer the Fermentation lasts, the more the microbes utilize the glucose contained in the hydrolyzed solution for metabolic processes. The ability of microbes to produce acid increases. A decrease in $\mathrm{pH}$ can measure an increase in acid. 60 hours of bioethanol fermentation with pineapple peel substitution and the addition of Saccharomyces cerevisiae affect lowering the $\mathrm{pH}$ value and Saccharomyces cerevisiae can ferment optimally at $\mathrm{pH} 4.5$.

\section{CONCLUSION}

$\mathrm{H}_{2} \mathrm{SO}_{4}$ used in the hydrolysis process has a major effect on the levels of bioethanol produced. The optimum concentration of $\mathrm{H}_{2} \mathrm{SO}_{4}$ on bioethanol production is $3 \%$, with bioethanol concentrations obtained $7 \%, 13 \%$, and $11 \%$ with a refractive index value obtained 1.33616, 1.33893, 1.33805 and the obtained $\mathrm{pH}$ is 5 .

Fermentation time in the manufacture of bioethanol has an important role in breeding microorganisms so that the breakdown of glucose into bioethanol becomes more optimal. The optimum fermentation time in making bioethanol is three days with bioethanol concentrations obtained $9 \%, 13 \%$, and $8 \%$ with the refractive index obtained. $1.33688,1.33893,1.336475$ with the obtained $\mathrm{pH} 5$

\section{ACKNOWLEDGMENTS}

The authors acknowledge funding by the Directorate General of Higher Education, Ministry of Education and Culture, following the Agreement for the Implementation of Research Assignment of Innovation Assignments.

Number: 3626/PL6.4.2/SK/2021 dated May 11, 2021

\section{REFERENCES}

[1] A. Bušić, N. Mardetko, S. Kundas, G. Morzak, H. Belskaya, M.I. Šantek, D. Komes, S. Novak, B. Šantek, Bioethanol production from renewable raw materials and its separation and purification: A review, Food Technol. Biotechnol. $56 \quad$ (2018) 289-311. https://doi.org/10.17113/ftb.56.03.18.5546.

[2] O.I. Mba, M.J. Dumont, M. Ngadi, Palm oil: Processing, characterization and utilization in the food industry - A review, Food Biosci. 10 (2015) 26-41. https://doi.org/10.1016/j.fbio.2015.01.003.

[3] D. Perkebunan, Statistik Perkebunan Indonesia (Tree Crop Estate Statistics Of Indonesia 2017 2019) Kelapa Sawit (Palm Oil), Dir. Gen. Estate Crop. Minist. Agric. Indones. (2019) 1-81. http://ditjenbun.pertanian.go.id.

[4] E.C. Sitepu, T. Sembiring, K. Sebayang, I. Sumirat, M. Rianna, E. Marlianto, S.G. Sukaryo, A study of the use of palm fiber and palm shell as a thermal neutron radiation shielding material, Case Stud. Therm. Eng. 14 (2019)

100468 
[5] S.H. Kong, S.K. Loh, R.T. Bachmann, S.A. Rahim, J. Salimon, Biochar from oil palm biomass: A review of its potential and challenges, Renew. Sustain. Energy Rev. 39 (2014) 729-739. https://doi.org/10.1016/j.rser.2014.07.107.

[6] E. Mardawati, M.T.A.P. Kresnowati, R. Purwadi, Y. Bindar, T. Setiadi, Fungal Production of Xylanase from Oil Palm Empty Fruit Bunches via Solid State Cultivation, Int. J. Adv. Sci. Eng. Inf. Technol. 8 (2018) 25392546. https://doi.org/10.18517/ijaseit.8.6.4196.

[7] N. Sahara, R. Fitria, A. Efi, Utilization of Young Coconut Fibers as Textile Dyes, Second Int. Conf. Cullinary, Fash. Beauty, Tour. 2019. (2020) 1-8. https://osf.io/preprints/cb7xa/.

[8] L. Ye, M.S. Bin Hudari, X. Zhou, D. Zhang, Z. Li, J.C. Wu, Conversion of acid hydrolysate of oil palm empty fruit bunch to L-lactic acid by newly isolated Bacillus coagulans JI12, Appl. Microbiol. Biotechnol. 97 (2013) 4831-4838. https://doi.org/10.1007/s00253-013-4788-y.

[9] J.K.W. Chang, X. Duret, V. Berberi, H. ZahediNiaki, J.M. Lavoie, Two-step thermochemical cellulose hydrolysis with partial neutralization for glucose production, Front. Chem. 6 (2018)
1-11.

https://doi.org/10.3389/fchem.2018.00117.

[10] Y. Yu, X. Lou, H. Wu, Some Recent Advances in Hydrolysis of Biomass in Hot-Compressed Water and Its Comparisons with Other Hydrolysis Methods, Energy and Fuels. 22 (2008) 46-60. https://doi.org/10.1021/ef7002969.

[11] M. Balat, H. Balat, C. Öz, Progress in bioethanol processing, Prog. Energy Combust. $\begin{array}{llll}\text { Sci. } & 34 & \text { (2008) } & \text { 551-573. }\end{array}$ https://doi.org/10.1016/j.pecs.2007.11.001.

[12] Tan, L., Yu, Y., Li, X., Zhao, J.,Qu, Y., Choo, Y.M., Loh, S.K., 2013, Pretreatment of Empty Fruit Bunch From Oil Palm for Fuel Ethanol Production , Bioresource Technology 135, 275282

[13 Nurfahmi, Ong, H. C., Jan, B.M,, Tong, C.W. Fauzi, H., Chen, W., H., 2016, Effects of Organosolv Pretreatment and Acid Hydrolysis on Palm Empty Fruit Bunch (PEFB) as Bioethanol Feedstock, Biomass and Bioenergy 95,

78-83 